\title{
Türkiye'de Özel Sektörün Kurumsal Sosyal Sorumluk Anlayışına İlişkin Yarar Algısı: Kurumsal Sosyal Sorumluluk Faaliyetlerinin Duyurulmasında Web Sitelerinin Kullanılması
}

\author{
Benefit Perception About the Understanding of Corporate Social Responsibility \\ in Pprivate Sector in Turkey: Using Web Sites for Announcing of Corporate \\ Social Responsibility Activities
}

\author{
Dr. Nuray YILMAZ SERT
}

ÖZET Kurumsal Sosyal Sorumluluk (KSS) anlayışı hem topluma hem kuruma değer katan bir kavram olarak bir yandan toplumsal refahın gelişmesine katkıda bulunurken öte taraftan kurumların bir toplumdaki varlıklarını sürdürebilmelerinin de temelini oluşturmaktadır. Dolayısıyla hayırseverlik anlayışından farklı olarak Kurumsal Sosyal Sorumluluk faaliyetlerinde kurumsal ve toplumsal olmak üzere iki tarafl yarar gözetilmektedir. Bu nedenle özellikle kurum yararının săglanabilmesi için sosyal sorumluluk çalışmalarından kamuoyunun haberdar edilebilmesi önemlidir. Günümüzde kurumsal web sitelerinin bu çalışmaların duyurulmasında etkin bir şekilde kullanıldı ̆̆̆ görülmektedir.

Bu çalışma öncelikle, Türkiye'de özel sektörün Kurumsal Sosyal Sorumluluk anlayışına ilişkin toplumsal ve kurumsal yarar algısını ortaya koymayı amaçlamaktadır. Ayrıca bu çalışmada, kurumsal yararın să̆lanabilmesi için KSS faaliyetlerinin duyurulmasında web sitelerinin kullanımı araştırılmaktadır. Çalışmanın ilk bölümünde, KSS kavramının içeriği, tarihsel gelişimi ve hayırseverlik anlayışından farklı yönleri açıklanmaktadır. İkinci bölümde, KSS kavramı ile ilişkili ekonomik yaklaşımlar ele alınmaktadır. Her iki bölümde de literatür taraması yapılarak, çalışma konusu bilimsel bir çerçevede incelenmektedir. Araştırmaya dayalı üçüncü bölümde ise, Capital dergisi tarafindan gerçekleştirilen "Türkiye'nin En Büyük 500 Özel Şirketi" araştırmasının 2011 yılında açıklanan sonuçlarına göre, genel merkezi İstanbul'da bulunan şirketlere yönelik bir anket uygulaması yapılarak elde edilen verilerin analizi sunulmaktadır. Ayrıca araştırmaya katılan şirketlerin kurumsal web siteleri incelenerek KSS faaliyetlerinin bu web sitelerinde yer alıp almadiğ Araştırmanın sonucuna göre, şirketlerin büyük bir çoğunluğu KSS faaliyetlerinin kurumsal yararları olduğunu kabul etse de toplumsal yararlarının kurumsal yararlarından fazla olduğu görüşündedir. KSS faaliyetlerinden sadece toplumsal yarar gözettiklerini belirten şirketlerin \% 67,6'sının kurumsal web sitelerinde bu tür faaliyetlerini açıklamadıkları bununla birlikte, KSS faaliyetlerinden hem toplum hem kurum yararn gözettiklerini belirten şirketlerin ise \% 79,1'inin kurumsal web sitelerinde bu tür faaliyetlerini duyurdukları görülmektedir.

Anahtar Sözcükler: Kurumsal Sosyal Sorumluluk, Türkiye'de Özel Sektör, Kurumsal Yarar, Toplumsal Yarar, Kurumsal Web Siteleri. 
ABSTRACT As a concept that adds value to both the society and the corporation, understanding of Corporate Social Responsibility (CSR), contributes to the development of social welfare on the one hand and also forms a basis for sustaining the existence of corporations in a society on the other hand. Consequently as distinct from philanthropy, two-sided benefits including institutional and social taken into account in Corporate Social Responsibility activities. Therefore especially in order to ensure the corporate benefit, it is important to be aware of the public about their works of social responsibility. Today it is observed that corporate web sites are used effectively for announcing these works.

This paper first of all aims to explore the perception of social and institutional benefit about the understanding of Corporate Social Responsibility in Private Sector in Turkey. In addition, the usage of corporate web sites for announcing of CSR activities, in order to ensure the corporate benefit, is also investigated in this study. In the first section of the study, the contents of CSR concept, its historical development and differences from philanthropy are described. In the second section, economic approaches that related to CSR are discussed. Subject of this study is examined in a scientific frame by doing a literature review for each of these two sections. In the third section which is based on research, according to results -announced 2011- of "Turkey's Top 500 Private Companies" research conducted by Capital magazine, a questionnaire was applied to the companies that headquarted in Istanbul then evaluation of the data's obtained from survey are given. In addition it is specified that whether CSR activities are taken place in the web sites or not by examining the corporate web sites of the companies which applied the survey. According the results of the study, although the majority of corporations accept the institutional benefit of Corporate Social Responsibility, they have an opinion that social benefit of CSR is more than its institutional benefit. It is observed that \% 67,6 of corporations, which look after only social benefit from CSR, don't explain this kind of activities on their corporate web sites however, \%79,1 of corporations which look after both social and institutional benefits from CSR, announce such activities on their corporate web sites.

Keywords: Corporate Social Responsibility, Private Sector in Turkey, Corporate Benefit, Social Benefit, Corporate Web Sites. 


\section{GİRiş}

Kurumsal Sosyal Sorumluluk; kurumların karlılık, süreklilik ve büyüme amaçları gibi ekonomik sorumluluklardan başlayıp hukuki, etik ve gönüllü sorumluluklara kadar yükselen bir doğru izlemektedir. Gerçekleştirdikleri faaliyetlerle tüm bu hedeflerine ulaşmaya çalışan kurumların, temelde ekonomik sorumlulukların yerine getirmeden diğer sorumlulukların gerçekleştirmesi mümkün değildir. Fakat aynı zamanda hukuki, etik ve gönüllü sorumluluklar, kurumların ekonomik amaçları üzerinde sınırlayıcı bir etkiye sahiptir. Ekonomik nedenlerle olsun ya da olmasın bir kurumun gerçekleştirdiği herhangi bir faaliyet sadece o kurumun kendisini değil aynı zamanda dış çevresini de etkilemektedir.

Günümüzde kurumların çoğunlukla üç yolla sosyal sorumluluk sergiledikleri görülmektedir. Bunlardan ilki, belirli amaçlar doğrultusunda kurumların kendi vakıflarını kurma yoluyla gerçekleştirdikleri sosyal sorumluluklardır. Örneğin; Sabancı Vakfı, Koç Vakfı, Tema Vakfı vb. İkinci olarak; Kurumlar Sosyal Sorumluluk kapsamında çeşitli sivil toplum kuruluşlarıyla ya da konuyla ilgili bakanlıklarla iş birliği yapma yoluna gitmektedirler. Buna örnek olarak, Turkcell'in Çağdaş Yaşamı Destekleme Derneği (ÇYDD) ile birlikte yürüttüğü Kardelenler Projesi gösterilebilir. Üçüncü ve son olarak ise; Yap1 Kredi'nin kendi çalışanlarından oluşturduğu Sınırsız Mavi Gönüllüleri isimli grubun deniz ve kıyı temizliği konusunda çeşitli etkinlik ve çalışmalarda bulunması örneğinde olduğu gibi kurumlar bir sivil toplum kuruluşu ya da bir vakıf olmaksızın da kendi kampanyalarını doğrudan kendileri yürütebilirler. Sonuçta hangi yolla olursa olsun asıl önemli olan, sadece farkındalık ve ilgi yaratmak değil, toplumsal bir baskı beklemeksizin Kurumsal Sosyal Sorumluluk bilincini kurum politikasıyla bütünleştirebilmek, ayrıca kamuoyunun inanılırlığını ve güvenini kazanabilmek için uzun vadeli ve devamlı olabilmektir.

Kurumsal Sosyal Sorumluluk çok geniş kapsamlı bir konudur. Dolayısıyla işletmelerin faaliyette bulunabilecekleri birçok sorumluluk alanı vardır. Bunları; işletmelerin tüketicilere, hissedarlara/sahiplere/yatırımcılara, çalışanlara, topluma, devlete, tedarikçilere, çevreye ve rakiplere karşı sorumlulukları olarak özetlemek mümkündür. Kurumsal Sosyal Sorumluluk projelerinin bu konulardan hangisine odaklandığı, ülkeden ülkeye, kültürden kültüre ve kurumların sosyal paydaş gruplarına göre farklılık gösterebilmektedir. Önemli olan kurumun, ihtiyaç duyulan bir alana yatırım yapmasıdır (Gürel, 2010: s.118). Türkiye'de iş çevrelerinin hem kendi iş faaliyetlerini, hem de toplumu geliştirebilmek için güçlü bir çaba sergilediği gözlemlenmektedir. Fakat şirketler genel olarak sosyal ve çevresel konulara odaklanmakta, insan hakları, çalışan hakları, çalışanların karar süreçlerine katılımı gibi konuların sosyal sorumluluk anlamında geliştirilmesine halen ihtiyaç duyulmaktadır (Göcenoğlu ve Onan, 2008: s.3).

\section{KURUMSAL SOSYAL SORUMLULUK KAVRAMI VE TARIHHSEL GELIŞSIMI}

Sorumluluk, kişinin kendi davranışlarının veya kendi yetki alanına giren herhangi bir olayın sonuçlarını üstlenmesi ya da yükümlülük almasıdır (Türkçe Sözlük,1988). J.E.Grunig ve J.White, "insanların ve organizasyonların kendi davranışlarının başkaları üzerindeki sonuçlarıyla ilgilenmesi ve kötü sonuçları ortadan kaldırmaya çalışması" olarak tanımlamaktadır (Grunig ve White, 2005: 57). Wood'a göre sorumluluk, bireylerin ve 
organizasyonların toplumun diğer aktörleri ile olan karşılıklı ilişkilerinde gömülüdür. $\mathrm{Ne}$ bireyler ne de organizasyonlar, karşılığında başkalarının hak ve özgürlüklerini tanımaya ve korumaya gönüllü olmadıkça, kendi haklarının ve özgürlüklerinin sağlanmasını talep edebilir (Aktaran Özüpek, 2005: 8). Sorumluluk kelimesi hem bireysel hem sosyal yönü olan bir kavramdır. Dolayısıyla içinde bulunulan toplumun değer yargılarına bağlı olarak sorumluluk anlayışı değişiklik gösterebilir.

Aynı şekilde sosyal sorumluluk kavramı da; bireylerin ve yönetimlerin, içinde yaşadıkları toplumun yaşam kalitesini iyileştirme ve sürdürülebilir bir dünya için bütün toplumla birlikte ekonomik, çevresel, kültürel ve sosyal gelişmeye destek verme sorumluluğu olarak tanımlanarak (http://www.sucsr.com/kurumsal-sosyalsorumluluk/makaleler/kssnedir.php, 11 Mart 2009) hem bireylerin hem kurumların topluma karşı sorumluluğunu ifade etmektedir.

Kurumsal Sosyal Sorumluluk kavramının ise, biraz daha farklı bir yönü vardır. S.D. Het Hof ve D.Çabuk'a göre Kurumsal Sosyal Sorumluluk kavramı, birey olarak varlıklı kişilere, işadamlarına ya da şirket genel müdürlerine (CEO) değil, kar amaçlı örgütlere, yani şirketlere ilişkindir ve bu şirketlerin büyük bir bölümü küreselleşme ile sayıları artan, güçlenen ve etki alanları genişleyen çok uluslu şirketlerdir. Kurumsal Sosyal Sorumluluk'daki kurumsal kavramı "bir tüzel kişilik olarak şirketlere ilişkin olan" anlamındadır ve bu açıdan bakıldığında bireylerle, kar amaçlı olan ya da olmayan örgütlerle, devlet birimleriyle ilişkilendirilerek kullanılabilecek sosyal sorumluluk ifadesinden farklı olarak şirketlerin toplumsal performansları ile ele alınan bir olguya işaret etmektedir (van Het Hof ve Çabuk, 2011: 49). Kurumsal Sosyal Sorumluluk, temel olarak işletmelerin üretim ve faaliyetlerini çevre, toplum ve etkileşim içinde bulunduğu tüm paydaşlarını dikkate alarak yerine getirmesidir (Ersöz, 2007:3).Başka bir ifadeyle işletmelerin ekonomik faaliyetlerinin onunla ilgili tarafların hiçbirinin menfaatlerine zarar verilmeden yönetilmesidir (Karakadılar, 2008). Farklı kaynaklarda çeşitli şekillerde açıklanmaya çalışılan Kurumsal Sosyal Sorumluluk kavramıla ilişkili tanımların çoğunda ortak olan dört unsurdan söz etmek mümkündür (Sönmez ve Bircan, 2004: 476-490):

1. İşletmelerin kar elde etmek için mal ve hizmet üretmelerinin ötesinde sorumlulukları vardır.

2. Bu sorumlulukların içinde, işletmelerin ortaya çıkmasına katkıda bulundukları sosyal problemlerin çözümüne katkıda bulunmak da vardır.

3. İşletmeler sadece hissedarlara karşı değil, sosyal paydaşlar olan çevreye karşı da sorumludurlar.

4. İşletmeler sadece ekonomik değerlere odaklanmamakta, daha geniş anlamda insani değerlere hizmet etmektedir.

Bu açıklamalarda dikkat edilmesi gereken husus, Kurumsal Sosyal Sorumluluğun sadece finansal katkılarla değil mal ve hizmet gibi finansal olmayan şekillerde de gerçekleştirilebileceğidir. Ayrıca bir kurumun doğrudan veya dolaylı etkileşim içinde olduğu/olabileceği herkese karşı sorumluluğunu ifade ettiği için kurumların sosyal sorumluluk girişimlerinin seçiminden geliştirilmesi ve uygulamaya konulmasına kadar 
alınan tüm kararlarda toplumun ihtiyaç ve beklentilerinin göz önünde bulundurulması gerekmektedir.

Toplumsal ihtiyaç ve beklentiler ise, tarih boyunca yaşanan koşullara göre sürekli değişmektedir. Dolayısıyla topluma karşı sorumlu olmak veya sorumlu davranmak anlayışı da toplum tarihi boyunca var olmakla birlikte tarihin her döneminde farklı şekillerde uygulanmıştır. Özellikle sanayi devriminden önceki dönemlerde dini değerler, toplumsal gelenek ve göreneklerle şekillenmiş olduğu görülen sosyal sorumluluk anlayışı çoğunlukla yardım ve bağış gibi hayır işleri ya da hayırseverlik anlamına gelmektedir. Kuramsal çerçeveden bakıldığında hayırseverlik Kurumsal Sosyal Sorumluluk anlayışının bir parçası olsa da her iki kavram arasında önemli farklar bulunmaktadır. Öncelikle Kurumsal Sosyal Sorumluluk, kurumların iş stratejilerine entegre olan bir değeri ifade etmektedir. Belirli bir sosyal konu hakkındaki farkındalığı ve ilgiyi arttırmak için özel olarak tasarlanmış iletişime yönelik çabalardır. Ayrıca sosyal sorumluluk uygulamaları kurumların toplumlara ve çevreye karşı gerçekleştirdikleri somut hareketleri gösterme fırsatını temsil ettiğinden dolayı kurumun kendisi tarafından ilan edilmektedir (Kotler ve Lee, 2008: 142-158). S.D.Het Hof ve Çabuk, kamuoyunun çeşitli yöntemlerle Kurumsal Sosyal Sorumluluk etkinliklerinden haberdar olmasının sağlanmasının KSS'nin önemli bir unsuru olduğunu belirtmektedir (van Het Hof ve Çabuk, 2011: 49). Günümüzde sosyal sorumluluk faaliyetlerinden kamuoyunu haberdar edebilmek için ise kurumların; kurumsal reklam, kurumsal faaliyet raporları, katolog, broşür, dergi ve tanıtım kitabı gibi geleneksel araçların yanısıra yeni medya araçlarından da etkin olarak yararlandıkları görülmektedir. Özellikle internetin yaygınlaşmasıyla birlikte hayatımıza giren web siteleri kurumların kendilerini kamuoyuna anlatabilecekleri bir araç olarak ön plana çıkmaktadır. Birçok kurumun web sitesinde tarih, vizyon, misyon, ürün ve hizmetler, yatırımc ilişkileri, kurumsal haberler, basın odası, insan kaynakları ve iletişim gibi temel bölümlere ek olarak, Kurumsal Sosyal Sorumluluk başlığ altında şirketlerin bu alanda gerçekleştirdikleri faaliyet ve projeleri de yer almaktadır. Web siteleri aracılığıyla kurumlar, hem kurumsal hem toplumsal yarar sağlayan sosyal sorumluluk uygulamalarından daha geniş kitleleri haberdar edebilme imkanı bulmuşlardır.

Kurumsal Sosyal Sorumluluk faaliyetlerinin duyurulma çabalarına karşın hayır işlerinin ise görünürlüğü daha azdır, hatta gizlilik prensibi esastır. Sonuç olarak, hayır işleri de toplum yararına olmakla birlikte iş sonuçlarına etkisi düşünülmemekte (Yazar, 2009:145), dolayısıyla geri dönüş anlamında kurumsal bir amaç taşımamakta ve bu yönüyle sosyal sorumluluktan ayrilmaktadır.

Hayır işlerinin ötesinde bugünkü modern anlamına yakın sosyal sorumluluk anlayışı ise, sanayi devrimi sonucu büyük işletmelerin ortaya çıkmasıyla birlikte gelişip kullanılmaya başlanan bir kavram olmuştur. Sanayileşme çağında işçi sınıfının haklarının istismar edilmesi, bunun sonrasında ortaya çıkan örgütlü toplu hareketler ve toplumun huzurunun tekrar sağlanmasını amaçlayan temel hak ve hürriyetlere ilişkin yasal düzenlemeler işverenleri çalışanlara ve toplumun beklentilerine karşı sorumluluk üstlenmeye ve sorumlu davranmaya zorlamıştır.

Sanayileşme sonrası şirketlerin toplumsal rolünün sorgulanmaya başlanmasıyla gelişen Kurumsal Sosyal Sorumluluk 1920'li yıllara kadar büyük bir kesim için sadece kar etmek 
anlayışı ile sınırlıdır. 1920'lerden itibaren ise iş dünyası ve iş adamlarının da bilinçli bir şekilde kendi toplumsal rollerini tartışmaya başladıkları görülmektedir. Yavaş yavaş sadece yöneticilerin ve hissedarların değil kredi veren, çalışan, tüketici, tedarikçi gibi şirkete diğer katkıda bulunanların çıkarlarının da korunarak, tatmin edici bir kar seviyesinin hedeflendiği bir yaklaşım benimsenmeye başlanmıştır. Fakat doğal çevre, kültür ve sanat gibi toplumsal etkinlikler 1920-1950 yılları arasındaki bu dönemde sorumluluk kapsaminda yer almamaktadır. 1950'lerde kamuoyunun baskısı işadamlarının sosyal sorumluluk kavramına olan ilgisini arttırmıştır. Gerçekleşen çalışmaların bir kısmında, işletmelerin kar etmenin dışında toplumun refahını arttırmaya yönelik faaliyetlerinin olması tavsiye edilmekle birlikte bunların kapsamı konusunda görüşler farklılaşmaktadır. Sosyal sorumluluk genelde çalışanlarla ilgili konular ile sınırlı kalmaktadır. Altmışlı ve yetmişli yıllardaki savaş karşıtı eylemler, tüketici hareketleri, çevrecilik ve kadın hakları konularında artan aktivizm işletmelerin toplumdaki rolünün tekrar gözden geçirilmesine neden olmuştur ve yeni bir sosyal sorumluluk anlayışının ilk örnekleri görülmeye başlanmıştır. Bu anlayışa göre, şirketlerin yöneticiler, hissedarlar ve şirkete diğer katkıda bulunanların dışında topluma karşı da sorumlulukları vardır ve toplumsal adalete katkıda bulunmak, doğayı korumak, kültürel ve sanatsal faaliyetlerin sürdürülmesi için payına düşeni yapmak vb. çalışmalar şirketlerin görevleri arasında bulunmaktadır. Fakat A.B.D'deki sosyo-ekonomik koşullar ve politikalar 80'li yıllarda şirketlerin sosyal sorumluluk uygulamalarında bir yavaşlatma gerçekleştirmiştir. Doksanlı yıllarda ise, tekrar kendini göstermeye başlayan aktivizmle birlikte şirketlerin sosyal sorumluluğunu tartışan, tanımlamaya, denetlemeye ve ölçmeye çalışan girişimlerin hızla arttığı ve 2000'li yıllarda işletmelerin toplumsal değişim aracı olarak ön plana çıtığı görülmektedir (Yamak, 2007: 15-95). Günümüzde işletmelerin sosyal sorumluluklarını yerine getirebilmek için devlet ya da toplumdan baskı beklemeksizin, toplumun refahını ve yaşam düzeyini geliştirmeye yardımcı faaliyetlere katılmaları beklenmektedir (Özüpek, 2005: 2).

Kurumsal Sosyal Sorumluluk kavramının tarihsel gelişimine Türkiye açısından bakıldığında da dünyadaki gelişimiyle benzer şekilde dini değerlerden kaynaklanan hayırseverlik kültüründen geliştiği söylenebilir. İnsanların doğası gereği toplum içinde yaşamalarının bir sonucu olarak ortaya çıkan hayır işlerinin İslam anlayışına göre kurumsallaşması ise Osmanlı toplumunda ahilik/lonca teşkilatı ve vakıflar yoluyla olmuştur. Günümüzdeki sosyal sorumluluk anlayışıyla birebir örtüşmese de Osmanlı Devleti'nde sosyal hayatın içinde önemli bir konuma sahip olan bu kurumların toplumsal dayanışmayı geliştirdiklerini yadsımak mümkün değildir. Gerçekte sosyal sorumluluk anlayışı toplumsal yapıya bağlı olarak gelişip şekillenmektedir. Türkiye'de ise son elli yılda uzun vadeli plan yapabilmek -sosyal sorumluluk anlayışı geliştirebilmek- için uygun politik ve ekonomik bir ortamın olmadığı söylenebilir. Ülkemizde ekonominin gelişmiş ülkelerin ekonomisiyle rekabet edebilecek düzeye gelmesi ancak 1980'den sonra olmuştur. Fakat bu süreçte artan rekabet, kurumları fiyat baskısı altında bırakmış ve karlılıklarını koruyabilmek için Kurumsal Sosyal Sorumluluk aktivitelerini ertelemeye itmiştir. Ancak 2001 yılındaki krizin ardından hayata geçirilen yapısal reformlar ekonomik bir büyüme sağlamıştır ve 2002 yılından beri gözlemlenen istikrarlı enflasyon oranları kurumların sosyal konulara eğilebilmeleri için uygun bir atmosfer yaratmıştır (Göcenoğlu ve Onan, 2008:7). Özellikle küreselleşmenin de etkisiyle uluslararası ticaretin yaygılaşması Türk şirketlerinin Kurumsal Sosyal Sorumluluk projelerine daha çok ilgi göstermesine yol açmıştır. 


\section{KURUMSAL SOSYAL SORUMLULUK ANLAYIŞINA İLIŞKİN YAKLAŞIMLAR}

Kurumsal Sosyal Sorumluluk anlayışı teorik olarak iki farklı ekonomik yaklaşımla açıklanmaya çalışılmıştır. Bunlardan ilki, kurumların amacının sadece kar elde etmek olduğunu ileri süren Klasik Ekonomik Yaklaşımdır. Diğeri ise; kurumların amacının hem toplumun refahını korumak ve geliştirmek hem de kar elde etmek olduğunu ileri süren Modern Ekonomik Yaklaşımdır.

Kurumsal stratejilerin, sosyal sorumluluk anlayışına yer vermemesi ya da çok az yer vermesi üzerine kurulu olan Klasik Ekonomik Yaklaşım'ın en önemli temsilcisi Milton Friedman'dır. M.Friedman'ın bu konudaki görüşleri serbest pazar yaklaşımı ya da hissedar yaklaşımı olarak adlandırılmaktadır.

Sosyal sorumluluk bilincine önem vermeyen serbest pazar yaklaşımı, pazarın devletin müdahaleleri yerine arz talep dengesine göre düzenlenmesi gerektiğini savunmaktadır. Bu görüşün savunucusu ekonomist M.Friedman, Kurumsal Sosyal Sorumluluğu reddetmektedir ve bu tür yükümlülüklerin sadece bireyler için geçerli olduğunu söylemektedir (Theaker, 2006:124-191). M.Friedman'a göre, bir işletmenin gerçek ve tek sorumluluğu yasalara uymak ve kar elde etmektir. Etik, sorumluluk ve vicdani duygular serbest pazar sistemindeki işletmelerin değil, sistemdeki görünmez elin için de yer almaktadır (Goodpaster ve Mathews, 2003: 141). Sosyal sorumluluk anlayışına ilk kez değinin iktisatçı Adam Smith'in 1876'da ortaya attığ1 görünmez el kuramına göre işletmelerin öncelikli amacı kar elde etmektir, ekonominin düzenlemesi ise, görünmeyen bir el tarafından gerçekleştirilecektir. Burada kastedilen, kazancını artırmaya ve zararını azaltmaya çalışan her bireyin, üretici ya da tüketicinin sonuçta farkında olmadan bütün toplumun refahına yardımcı olduğu (Öcal, 2007: 60, dolayısıyla da sosyal harcamaların gereksiz olduğudur. Başka bir anlatımla, Smith'e göre, bireyler ve kurumlar kendi çıkarlarını gözetirken ister istemez topluma da katkı sağlayarak sosyal sorumluluklarını da bir şekilde yerine getirmektedirler.

M.Friedman ayrıca, sosyal sorumluluk için yapılan harcamaların kurumların maliyetlerine ve fiyatlarına yansıyacağını, bunun da hissedarların karlarını ve çalışanların maaşlarını azaltırken tüketicilerin ürün için ödeyeceği fiyatları artıracağını belirtmektedir. Dolayısıyla kurumların kaynaklarının sosyal amaçlar için kullanılması pazar mekanizmalarını bozmakta, birileri de bunun maliyetini ödemek zorunda kalmaktadır (Özüpek, 2005: 35). Bu durum ise yeni bir sosyal sorumluluğu ifade ederken (Öcal, 2007:61) aynı zamanda da işletmelerin öncelikle kar amacıyla hareket eden ve hissedarların sermayesinin getirisini artıran kuruluşlar olduğu anlayışına da ters düşmektedir. Serbest pazar yaklaşımında kurumların menfaati ön planda tutulmakta toplumun bundan dolaylı olarak yarar sağladığı ileri sürülmektedir.

Öte yandan M.Friedman, şirket yöneticilerinin toplumsal açıdan neyin iyi neyin kötü olduğuna karar vermek konusunda yeterli olup olmadıklarını da sorgulamaktadır. Ona göre şirketlerin tek sorumluluğu kaynaklarını açı ve serbest bir rekabet ortamında, her hangi bir yolsuzluğa başvurmadan karlarını artırmak amacıyla kullanmaktır. Dolayısıyla şirketin temel sorumluluğunun hissedarlara karşı olduğunu belirtmektedir. Üniversitelere bağış 
yapmak gibi toplumsal refahı arttırmak yönündeki çalı̧̧maların ise şirketin değil, hissedarın kendi tasarrufunda olması gerektiğini savunmaktadır (Yamak, 2007: 39).

M.Friedman'ın bu görüşlerine karşın günümüzde kurumlar çoğunlukla toplumun refahına katkı sağlayan Modern Ekonomik Yaklaşım'ı benimsemiş ve sosyal sorumluluk stratejik yönetimin önemli bir parçası olmuştur. Kurumların amacının hem toplumun refahını korumak ve geliştirmek hem de kar elde etmek olduğunu ileri süren Modern Ekonomik Yaklaşım genelde paydaşlar teorisiyle açıklamaktadır.

Kurumsal Sosyal Sorumluluk konusundaki çalışmalarda paydaş kavramının sık sık kullanıldığı görülmektedir. Bu kavram ilk defa 1963 yılında Edward Freeman tarafından kullanılmıştır. E.Freeman'ın tanımına göre paydaş; bir kurumun faaliyetlerinden etkilenen ya da bu faaliyetleri etkileyen kesimi ifade etmektedir (Öcal, 2007: 82). Daha geniş anlamıyla bir kurumla ilişkisi olan, o kurumun davranışlarından olumlu/olumsuz etkilenen ve kurumu olumlu/olumsuz etkileyen kişiler, gruplar, diğer kurum ya da kuruluşlar olarak açıklamak mümkündür. Bu açılamalara dayanarak paydaşlar, bir kurumun ilişkide olduğu tüm kesimlerdir denilebilir. Fakat zamanla kurumların ilişkide olduğu kesimlerin sayısı da arttığ için, paydaşların sınıflandırılması da yapılan çalışmalarda değişiklik göstermektedir. Paydaşların sınıflandırılmasına ilişkin farklılıklar kurumların faaliyet gösterdikleri alana bağlı olarak da değişmektedir.

J.A.Stoner v.d., bir organizasyonun çevresini dış ve iç çevre olmak üzere ikiye ayırarak ele almaktadırlar. Dış çevre, hem doğrudan ve hem dolaylı faaliyet elemanlarını kapsamaktadır. Bir organizasyonun doğrudan faaliyet elemanları, paydaşlarıdır. Paydaşlar da iki ayrı kategoride incelenmektedir. Bunlar; bir organizasyonun davranışlarını etkileyen sendikalar, tedarikçiler, rakipler, tüketiciler, özel çıkar grupları, kamu kuruluşları gibi birey ya da grupların oluşturduğu dış paydaşlar ve çalışanlar, hissedarlar ve yönetim kurulunun oluşturduğu iç paydaşlardır. Dolaylı faaliyet elemanları ise, bir organizasyonun faaliyet ortamını etkileyen teknoloji, ekonomi ve politika gibi unsurları içermektedir (Stoner ve Freeman, 1995: 63).

Daha öncede belirtildiği gibi paydaşların sınıflandırılmasına ilişkin farklı yaklaşımlar mevcuttur. Örneğin, M.Clarkson paydaşları, kurumla doğrudan ilişki içinde olan birincil paydaşlar ve dolaylı ilişkide bulunan ikincil paydaşlar olarak iki grup altında ele almaktadır. Devamlı katılımları olmazsa kurumların faaliyetlerini sürdüremedikleri birincil paydaşlar; hissedarlar, yatırımcılar, çalışanlar, tüketiciler ve tedarikçilerin yanı sıra altyapı ve pazar hizmetleri sağlayan hükümetler ve diğer topluluklardır. Uyulması gereken kanun ve yönetmeliklerin, vergi ve yükümlülüklerin olduğu hükümet ve diğer topluluklar kamusal paydaşlar olarakta adlandırılmaktadır. İkincil paydaşları ise, kurumu etkileyebilen ve kurumun faaliyetlerinden etkilenebilen fakat kurumun devamlılığ için esas oluşturmayan rakipler, baskı grupları ve medya oluşturmaktadır (Moir, 2001:19). Birincil ve ikincil paydaşlar, kurum içi ve kurum dışı paydaşlar olarakta adlandırılmaktadır.

W.Werther ve D.Chander, paydaşları örgütsel paydaşlar, ekonomik paydaşlar ve sosyal paydaşlar olmak üzere üç grup altında ele almaktadır. Örgütsel paydaşlar, işletmenin içinde yer alan ve işletmenin faaliyetlerinden etkilenen gruplardır. Çalışanlar, müdürler, 
hissedarlar vb. İkinci grubu oluşturan ekonomik paydaşlar, bir kurum ve o kurumun sosyal çevresi arasında arabirim olarak hizmet etmektedir. Özellikle tüketiciler kurumların toplumla etkileşim içine girmesini sağlayan araç konumundadırlar. Ekonomik arabirim olmadan organizasyonlar uzun vadede sorumluluk mekanizmasını dolayısıyla da meşruluklarını kaybetmektedirler. Tüketiciler, alacaklılar, bayiler ve tedarikçiler ekonomik paydaşları oluşturmaktadır. Son grup, kurumların faaliyet gösterdikleri çevreleri olarak tanımlanan sosyal paydaşlardır. Hükümet organları, yasa koyucular, topluluklar, sivil toplum kuruluşları ve çevrenin kendisi sosyal paydaşları oluşturmaktadır (Werther ve Chandler, 2006:4,86). Ne şekilde adlandırılıyor olursa olsun Kurumsal Sosyal Sorumluluk kurumların tüm paydaşlarına karşı sorumluluğunu ifade etmektedir.

Serbest pazar yaklaşımın aksine paydaşlar yaklaşımı devletin, toplumun ve ekonominin karşılıklı ilişkisine ve etkileşimine dayandırılmaktadır. Paydaşlar yaklaşımında kurumların paydaşları ile kurdukları demokratik ilişkiler önemlidir. Bu yaklaşım kurumların tüm paydaşlarına karşı sosyal sorumluluklarını yerine getirmesini zorunlu kılmaktadır (Theaker, 2006:124). E.Freeman'a göre, işletme dışı gruplarla ne kadar güçlü ilişkiler kurulursa ortak hedeflerin gerçekleştirilmesi o kadar kolaylaşacak, aksi halde ilişkiler kötüleştikçe ortak hedeflere ulaşılması zorlaşacaktır. Stratejik bir yönetim kavramı olan paydaş teorisinin amacı, rekabet avantajı geliştirmek için kurumun iç ve dış çevresi ile olan ilişkilerini güçlendirmesine yardımcı olmaktır (Aktan ve Börü, 2007: 14).

Tarihsel gelişimine bakıldığında kurumların nihai amaçları uzun süre, hissedarların ve sahiplerinin karlarını maksimize etmek olarak görülmüştür. Oysa paydaşçı yaklaşıma göre, kurumların sadece hissedarların ve yöneticilerin çıkarları ile yönetilemeyeceği bunun yanı sıra diğer tüm paydaşlarının çıkarlarının da dikkate alınması gerektiği belirtilmektedir. Çünkü bir kurumla ilişkide bulunan her kesimin kendi açısından çıkar, amaç ve beklentileri mevcuttur (Özüpek, 2005: 5). Paydaşlar yaklaşımı tüm bu farklı kesimlerin çıkarlarını göz önünde bulundurmayı gerektirmektedir. Böylece bütün grupların belli bir dereceye kadar memnun edilmesi veya en azından belirli bir problemle ilgili en önemli paydaşların tatmin edilmesi amaçlanmaktadır (Sönmez ve Bircan, 2004: 476-490).

\section{ARAŞTIRMA}

A. Kurtkan'a göre, bir araştırmanın iki temel amacı vardır: Bunlardan birincisi "bilgiyi toplama" ve ikincisi de "bilgiyi ölçme" amaçlarıdır (Kurtkan, 1978: 226).

\subsection{Araştırmanın Amacı}

Çalışmaya konu olan bu araştırmanın amacı da, anket yoluyla toplanan bilgileri ölçümleyerek Türkiye'de özel sektör tarafından gerçekleştirilen Kurumsal Sosyal Sorumluluk faaliyetlerine ilişkin kurumsal ve toplumsal yarar algısını ortaya koyabilmek, ayrıca kurumsal yararın sağlanabilmesi açısından sosyal sorumluluk faaliyetlerinin kurumsal web sitelerinde duyurulma oranını belirlemektir. 


\subsection{Araştırmanın Yöntem ve Kapsamı}

Türkiye'de özel sektör tarafından gerçekleştirilen Kurumsal Sosyal Sorumluluk faaliyetlerine ilişkin toplumsal ve kurumsal yarar algısının incelenmesine yönelik bu araştırmada, amaca yönelik veri toplama aracı olarak anket çalışması ve kurumsal web siteleri üzerinden içerik analizi yapılmıştır. Belirlenen amaç doğrultusunda bu çalışmanın evrenini, aylık ekonomi dergisi Capital tarafından 1998 yılından beri gerçekleştirilen ve “Türkiye'nin En Büyük 500 Özel Şirketi” araştırması 2011 yılı listesinde yer alan şirketler oluşturmaktadır. Bilimsel çalışmalarda, üzerinde çalışma yürütülen hedef çalışma evreni hakkında fikir sahibi olmak ve çalışma sonucunu tüm çalışma evrenine genelleme yapmak için o evrendeki öğelerden oluşması hedeflenen grup örnek ya da örneklem olarak adlandırılmaktadır (Böke, 209: 106). Bu çalışmanın örnek grubunu, “Türkiye'nin En Büyük 500 Özel Şirketi" araştırması 2011 yılı listesinin illere göre dağılımında İstanbul ilinde yer alan 276 şirketler oluşturmaktadır. Bu şirketlerden sekizinin ismi açılanmamıştır. Dolayısıyla sayı 268'e düşmektedir. Bazı kurumlar ise, birden fazla şirketiyle listede yer almaktadır. Bu şirketler tek bir genel merkezden yönetilmektedir, yönetim kadroları aynıdır. Başka bir ifadeyle, hepsinin kurumsal iletişim faaliyetleri aynı kişi tarafından yürütülmektedir. Tüm bunlar dikkate alındığında örnek grup listesinde yer alan şirket sayısı 226 olarak belirlenmiştir. 226 şirketten 132'si $(\% 58,4)$ çalışmaya katılmıştır. 17 şirket iş yoğunluğu, şirket prensibi veya bazı tereddütleri olduğu gerekçesiyle ya da bir gerekçe sunmaksızın anketimize katılamayacaklarını belirtmişlerdir. Geri kalan 77 şirket ise olumlu veya olumsuz hiçbir geri dönüşte bulunmamıştır. Araştırmamıza katılan 132 şirketten 24'ü anket formunun girişinde yer alan "Şirketiniz Kurumsal Sosyal Sorumluluk faaliyetlerinde bulunuyor mu?" sorusuna "Hayır" yanıtını vermişlerdir. Bu soru, araştırmanın filtre sorusudur. Filtre sorular, soruların yalnızca soru kapsamında olan kişilerce yanıtlanmasını sağlamaktadır (Sevinç, 2009: 262). Bu çalışma da, özel sektördeki Kurumsal Sosyal Sorumluluk faaliyetlerinde gözetilen kurumsal ve toplumsal yararların ölçülmesi amaçlandığından KSS faaliyetinde bulunmadığını belirten bu 24 şirket sayısal değerlendirmeden ayrı tutulmuştur. Filtre sorusuna "Evet" yanıtını veren 108 şirket bulunmaktadır. 108 şirketten $4^{\prime}$ ü ankette yer alan bazı soruları eksik doldurduğu için değerlendirilmeye alınmamış, sadece 104 anket geçerli kabul edilerek değerlendirmeye alınmıştır. Ayrıca yanıtları geçerli sayılan bu 104 şirketin kurumsal web siteleri taranmış ve sosyal sorumluluk faaliyetlerine yer verilip verilmediği incelenmiştir. Araştırma sonucu elde edilen veriler SPSS (Statistical Package for Social Sciences) for Windows 17.0 programı kullanılarak analiz edilmiştir. Veriler değerlendirilirken tanımlayıcı istatistiksel metotları (frekans, yüzde, ortalama ve karşılaştırma) kullanılmıştır.

A.PaşAıra Kurumsal Sosyal Sorumluluk faaliyetlerinin en fazla Kurumsal İletişim (\% 39,4) ve İnsan Kaynakları Departmanı (\% 36,5) tarafından yürütüldüğü görülmektedir. Araştırmaya katılan bazı şirketler holding kuruluşlarıdır. Holding bünyesinde tek bir Kurumsal İletişim Departmanı mevcuttur ve Kurumsal Sosyal Sorumluluk çalışmaları holding şirketlerinin bünyesindeki İnsan Kaynakları departmanıyla koordineli olarak yürütülmektedir. 
Tablo 1. Cinsiyet Dağılımı

\begin{tabular}{|l|c|c|}
\hline & Frekans (n) & Yüzde (\%) \\
\hline Erkek & 37 & 35,5 \\
\hline Kadın & 67 & 64,4 \\
\hline Toplam & 104 & 100,0 \\
\hline
\end{tabular}

Araştırma formunu yanıtlayanların cinsiyetlerine göre dağılımı Tablo 1'de incelenmiştir. Buna göre, araştırmaya katılanların 37'si (\% 35,5) erkek, 67'si (\% 64,4) kadındır.

Tablo 2. Yaş Dağılımı

\begin{tabular}{|l|c|c|}
\hline & Frekans $\mathbf{( n )}$ & Yüzde (\%) \\
\hline $20-25$ yaş & 10 & 9,6 \\
\hline $26-30$ yaş & 17 & 16,3 \\
\hline $31-35$ yaş & 33 & 31,7 \\
\hline 36-40 yaş & 19 & 18,2 \\
\hline $41-45$ yaş & 13 & 12,5 \\
\hline 46 yaş ve üzeri & 12 & 11,5 \\
\hline
\end{tabular}

Araştırma formunu yanıtlayanların yaşlarına göre dağılımı Tablo 2'de incelenmiştir. Buna göre, araştırmaya katılanların 10'u (\% 9,6) 20-25 yaş, 17'si (\% 16,3) 26-30 yaş, 33'ü (\% 31,7) 31-35 yaş, 19'u (\% 18,2) 36-40 yaş, 13'ü $(\% 12,5) 41-45$ yaş, 12'si $(11,5) 46$ yaş ve üzeri yaş aralığındadır.

Tablo 3. Eğitim Durumuna Göre Dağılım

\begin{tabular}{|l|c|c|}
\hline & Frekans (n) & Yüzde (\%) \\
\hline Ortaokul & 0 & 0 \\
\hline Lise & 3 & 2,8 \\
\hline Önlisans & 8 & 7,6 \\
\hline Lisans & 67 & 64,4 \\
\hline Yüksek Lisans & 26 & 25 \\
\hline Doktora & 1 & 0,9 \\
\hline
\end{tabular}

Araştırma formunu yanıtlayanaların eğitim durumlarına göre dağılımı Tablo 3'de incelenmiştir. Buna göre, araştırmaya katılanların 3'ü (\% 2,8) lise, 8'i $(\%$ 7,6) önlisans, 67'si (\% $64,4)$ lisans, 26 's1 (\% 25) yüksek lisans ve 1'i $(\% 0,9)$ doktora mezunudur. 
Tablo 4. Kurumsal Sosyal Sorumluluk Faaliyetlerinin Yürütüldüğü Departmana Göre Dağılım

\begin{tabular}{|l|c|c|}
\hline $\begin{array}{l}\text { KSS faaliyetleriniz hangi departman tarafından } \\
\text { yürütülmektedir? }\end{array}$ & Frekans(n) & Yüzde (\%) \\
\hline Halkla İlişkiler ve Tanıtım Departmanı & 6 & 5,8 \\
\hline Halkla ilişkiler ve Reklam Departmanı & 4 & 3,8 \\
\hline Kurumsal İletişim Departmanı & 41 & 39,4 \\
\hline İnsan Kaynakları Departmanı & 38 & 36,5 \\
\hline Genel Müdürlük & 19 & 18,3 \\
\hline Kurum Dışı Bir Ajans & 3 & 2,9 \\
\hline Diğer & 20 & 19,2 \\
\hline
\end{tabular}

Kurumsal Sosyal Sorumluluk faaliyetlerinin yürütüldüğ̈̈ departmanlara göre dağılımı Tablo 4'de incelenmiştir. Buna göre, araştırmaya katılanların 6'sının (\% 5,8) Halkla İlişkiler ve Tanıtım Departmanı, 4'ünün (\% 3,8) Halkla İlişkiler ve Reklam Departmanı, 41'inin (\% 39,4) Kurumsal İletişim Departmanı, 38'inin (\% 36,5) İnsan Kaynakları Departmanı, 19'unun (\% 18,3) Genel Müdürlük, 3'ünün (\% 2,9) kurum dışı bir ajans tarafından Kurumsal Sosyal Sorumluluk faaliyetleri yürütülmektedir. Ayrıca araştırmaya katılanların 20'si $(\% 19,2)$ anket formunun ikinci sorusundaki diğger seçeneğini de işaretlemiştir. Bu seçenekte belirtilen yanıtlara göre, şirketlerin Kurumsal Sosyal Sorumluluk faaliyetlerini yürüten ya da yürütülmesine yardımcı olan diğer departmanlar şunlardır: 1.Kurumsal Sorumluluklar ve Sponsorluklar Departmanı, 2.Pazarlama Departmanı, 3.İletişim Departmanı, 4.Kurumsal İletişim Müdürlüğü, 5.Markalar Departmanı, 6.Pazarlama İletişimi Departmanı, 7.Vakıf, Kalite Departmanı, 8.Kurumsal Sosyal Sorumluluk Departmanı, 10.İş Geliştirme Departmanı, 11.Kurumsal Sürdürülebilirlik Ekipleri, 12.Kategori Yönetimi Departmanı, 13.Amerika Merkezde Sosyal Sorumluluk Departmanı, 14.Her departman kendi bünyesinde.

Tablo 5. Kurumsal Sosyal Sorumluluk Faaliyetlerinin Yoğunlaştığı Alanlara Göre Dağılım

\begin{tabular}{|l|c|c|}
\hline $\begin{array}{l}\text { KSS faaliyetleriniz daha çok hangi } \\
\text { alanlarda yoğunlaşmaktadır? }\end{array}$ & Frekans (n) & Yüzde (\%) \\
\hline Spor & 19 & 18,3 \\
\hline Sağllk & 36 & 34,6 \\
\hline Doğa ve Çevre & 49 & 47,1 \\
\hline Sanat ve Kültür & 30 & 28,8 \\
\hline Eğitim ve Öğretim & 82 & 78,8 \\
\hline Gönüllü çalışmalar & 31 & 29,8 \\
\hline Diğer & 11 & 10,6 \\
\hline
\end{tabular}

Araştırmaya katılan şirketlerin Kurumsal Sosyal Sorumluluk faaliyetlerinin yoğunlaştığı alanlara göre dağılımı Tablo 5'de incelenmiştir. Buna göre, araştırmaya kurumların 19'unun (\% 18,3) spor, 36'sının (\% 34,6) sağlik, 49'unun (\% 47,1) doğa ve çevre, 30'unun (\% 28,8) sanat ve kültür, 82 'sinin $(\% 78,8)$ eğitim ve öğretim, 31'inin (\% 29,8) gönüllü çalışmalar alanında 
yoğunlaştı̆̆1 görülmektedir. Araştırmaya katılanların 74'ü (\%71.15) birden fazla alanda faaliyette bulunduklarını belirtmiştir. Ayrıca araştırmaya katılanların 6'sı $(\% 5,7)$ anket formunun üçüncü sorusundaki diğer seçeneğini de işaretlemiştir. Diğer seçeneğinde belirtilen faaliyet alanları şunlardır: İstihdam, Trafik ve yol güvenliği, Tarım, Çocuk, Aile içi şiddet, Cami ve kuran kursu

Tablo 6. Kurumların Sosyal Sorumluluk Faaliyetlerden Gözettiği Yararlara Göre Dağılım

\begin{tabular}{|l|c|c|}
\hline \multicolumn{1}{|c|}{ Aşağıdaki ifadelerden sizin için uygun olanını işaretleyiniz. } & Frekans (n) & Yüzde (\%) \\
\hline $\begin{array}{l}\text { Kurumsal Sosyal Sorumluluk faaliyetlerinde toplum yararı } \\
\text { gözetilir. }\end{array}$ & 37 & 35,6 \\
\hline $\begin{array}{l}\text { Kurumsal Sosyal Sorumluluk faaliyetlerinde kurum yararı } \\
\text { gözetilir. }\end{array}$ & 0 & 0 \\
\hline $\begin{array}{l}\text { Kurumsal Sosyal Sorumluluk faaliyetlerinde hem toplum hem } \\
\text { kurum yararı gözetilir. }\end{array}$ & 67 & 64,4 \\
\hline
\end{tabular}

Araştırmaya katılanların Kurumsal Sosyal Sorumluluk uygulamalarından gözettikleri yararlara göre dağılımı Tablo 6'da incelenmiştir. Buna göre araştırmaya katılanların 37'sinin (\% 35,6) Kurumsal Sosyal Sorumluluk uygulamalarında toplum yararı gözettiği, 67'sinin (\% $64,4)$ Kurumsal Sosyal Sorumluluk uygulamalarında hem toplum hem kurum yarar1 gözettiği görülmektedir. Araştırmanın sonucuna göre, Kurumsal Sosyal Sorumluluk uygulamalarında sadece kurum yararı gözeten şirket bulunmamaktadır.

Tablo 7. Kurumsal Sosyal Sorumluluk Faaliyetlerinin Toplumsal Yararlar Anlayışına Göre Dağııımı

\begin{tabular}{|c|c|c|c|c|c|c|}
\hline $\begin{array}{l}\text { KSS faaliyetlerinin toplumsal yararlarıyla } \\
\text { ilgili olarak aşağıda yer alan ifadelerin } \\
\text { sizin için katılım derecelerini belirtiniz. }\end{array}$ & $\begin{array}{l}\text { Frekans (n) } \\
\text { ve } \\
\text { Yüzde (\%) }\end{array}$ & 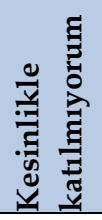 & 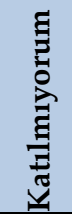 & 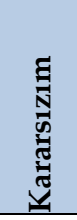 & 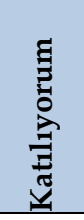 & 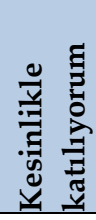 \\
\hline \multirow{2}{*}{ KSS, toplumsal refahı iyileştirir. } & Frekans (n) & 1 & 4 & 5 & 56 & 38 \\
\hline & Yüzde (\%) & 0,9 & 3,8 & 4,8 & 53,8 & 36,5 \\
\hline \multirow{2}{*}{$\begin{array}{l}\text { KSS, çevreye karşı bir toplumdaki } \\
\text { bilinçliliği artırır. }\end{array}$} & Frekans (n) & 2 & 1 & 3 & 46 & 52 \\
\hline & Yüzde (\%) & 1,9 & 0,9 & 2,8 & 44,2 & 50 \\
\hline \multirow{2}{*}{$\begin{array}{l}\text { KSS, doğal kaynakların gelecek nesillere } \\
\text { aktarılmasına katkıda bulunur. }\end{array}$} & Frekans (n) & 2 & 2 & 9 & 47 & 44 \\
\hline & Yüzde (\%) & 1,9 & 1,9 & 8,6 & 45,1 & 42,3 \\
\hline \multirow{2}{*}{ KSS, eğitimin yaygınlaşmasını sağlar. } & Frekans (n) & 2 & 1 & 8 & 49 & 44 \\
\hline & Yüzde (\%) & 1,9 & 0,9 & 7,6 & 47,1 & 42,3 \\
\hline \multirow{2}{*}{$\begin{array}{l}\text { KSS, kültür ve sanat alanındaki gelişmeleri } \\
\text { hızlandırır. }\end{array}$} & Frekans (n) & 2 & 4 & 9 & 46 & 43 \\
\hline & Yüzde (\%) & 1,9 & 3,8 & 8,6 & 44,2 & 41,3 \\
\hline \multirow{2}{*}{$\begin{array}{l}\text { KSS, kültürel mirasın korunmasına katkı } \\
\text { sağlar. }\end{array}$} & Frekans (n) & 2 & 2 & 8 & 52 & 40 \\
\hline & Yüzde (\%) & 1,9 & 1,9 & 7,6 & 50 & 38,4 \\
\hline \multirow{2}{*}{$\begin{array}{l}\text { KSS, toplumsal sorunların çözümüne katkı } \\
\text { sağlar. }\end{array}$} & Frekans (n) & 1 & 3 & 10 & 46 & 44 \\
\hline & Yüzde (\%) & 0,9 & 2,8 & 9,6 & 44,2 & 42,3 \\
\hline \multirow{2}{*}{$\begin{array}{l}\text { KSS, tüketicilerin yaşam kalitesini } \\
\text { yükseltir. }\end{array}$} & Frekans (n) & 1 & 14 & 23 & 42 & 24 \\
\hline & Yüzde (\%) & 0,9 & 13,4 & 21,1 & 40,3 & 23,0 \\
\hline \multirow{2}{*}{$\begin{array}{l}\text { KSS, insan haklarına saygi, eşitlik, sosyal } \\
\text { adalet vb. kavramların bir toplumda } \\
\text { yerleşmesini sağlar. }\end{array}$} & Frekans (n) & 1 & 5 & 14 & 44 & 40 \\
\hline & Yüzde (\%) & 0,9 & 4,8 & 13,4 & 42,3 & 38,4 \\
\hline
\end{tabular}




\begin{tabular}{|c|c|c|c|c|c|}
\hline Frekans (n) & 2 & 3 & 5 & 38 & 56 \\
\hline Yüzde (\%) & 1,9 & 2,8 & 4,8 & 36,5 & 53,8 \\
\hline
\end{tabular}

Kurumsal Sosyal Sorumluluk faaliyetlerinin toplumsal yararlarına ilişkin soruya verilen yanıtların dağılımı Tablo 7'de incelenmiştir. Buna göre "KSS toplumsal refahı iyileştirir" ifadesini araştırmaya katılanların 1'i $(\% \quad 0,9)$ kesinlikle katılmıyorum, 4'ü $(\% \quad 3,8)$ katılmiyorum, 5'i (\% 4,8) kararsızım, 56's1 (\% 53,8) katılıyorum ve 38'i (\% 36,5) kesinlikle katılıyorum olarak yanıtlamıştır. "KSS, çevreye karşı bir toplumdaki bilinçliliği artırır." ifadesini araştırmaya katılanların 2'si (\% 1,9) kesinlikle katılmıyorum, 1'i $(\% 0,9)$ katılmıyorum, 3'ü (\% 2,8) kararsızım, 46'sı (\% 44,2) katılıyorum ve 52'si (\% 50) kesinlikle katılıyorum olarak yanıtlamıştır. "KSS, doğal kaynakların gelecek nesillere aktarılmasına katkıda bulunur." ifadesini araştırmaya katılanların 2'si (\% 1,9) kesinlikle katılmıyorum, 2'si (\% 1,9) katılmiyorum, 9'u (\% 8,6) kararsızım, 47'si (\% 45,1) katıliyorum ve 44'ü (\% 42,3) kesinlikle katılıyorum olarak yanıtlamıştır. "KSS, eğitimin yaygınlaşmasını sağlar." ifadesini araştırmaya katılanların 2'si (\% 1,9) kesinlikle katılmıyorum, 1'i (\% 0,9) katılmıyorum, 8'i (\% 7,6) kararsızım, 49'u (\% 47,1) katılıyorum ve 44'ü (\% 42,3) kesinlikle katılıyorum olarak yanıtlamıştır. "KSS, kültür ve sanat alanındaki gelişmeleri hızlandırır." ifadesini araştırmaya katılanların 2'si (\% 1,9,) kesinlikle katılmıyorum, 4'ü (\% 3,8) katılmıyorum, 9'u $(\%$ 8,6) kararsızım, 46'sı (\% 44,2) katılıyorum ve 43'ü (\% 41,3) kesinlikle katılıyorum olarak yanıtlamıştır. "KSS, kültürel mirasın korunmasına katkı sağlar." ifadesini araştırmaya katılanların 2'si (\% 1,9) kesinlikle katılmiyorum, 2'si (\% 1,9) katılmıyorum, 8'i $(\% 7,6)$ kararsızım, 52'si (\% 50) katılıyorum ve 40'1 (\% 38,4) kesinlikle katıllyorum olarak yanıtlamıştır. "KSS, toplumsal sorunların çözümüne katkı sağlar.” ifadesini araştırmaya katılanların 1'i (\% 0,9) kesinlikle katılmıyorum, 3'ü (\% 2,8) katılmiyorum, 10'u $(\% 9,6)$ kararsızım, 46'sı (\% 44,2) katılıyorum ve 44'ü (\% 42,3) kesinlikle katılıyorum olarak yanıtlamıştır. "KSS, tüketicilerin yaşam kalitesini yükseltir." ifadesini araştırmaya katılanların 1'i (\% 0,9) kesinlikle katılmiyorum, 14'ü (\% 13,4) katılmıyorum, 23'ü (\% 22,1) kararsızım, 42'si (\% 40,3) katılıyorum ve $24^{\prime}$ ü $(\%$ 23,0) kesinlikle katılıyorum olarak yanıtlamıştır. "KSS, insan haklarına saygı, eşitlik, sosyal adalet vb. kavramların bir toplumda yerleşmesini sağlar." ifadesini araştırmaya katılanların 1'i $(\% 0,9)$ kesinlikle katılmıyorum, 5' $\mathrm{i}$ (\%4,8) katılmiyorum, 14'ü (\% 13,4) kararsızım, 44’ü (\%42,3) katıliyorum ve 40’1 $(\% 38,4)$ kesinlikle katılıyorum olarak yanıtlamıştır. "KSS, toplumsal dayanışmayı artırır." ifadesini araştırmaya katılanların 2'si (\% 1,9) kesinlikle katılmıyorum, 3'ü (\% 2,8) katılmıyorum, 5'i (\% 4,8) kararsızım, 38'i (\% 36,5) katıliyorum ve 56's1 (\% 53,8) kesinlikle katıliyorum olarak yanıtlamıştır.Araştırmaya katılanların 18'i $(\%$ 17,3) anket formunun beşinci sorusunda yer alan diğer seçeneğini de işaretlemiştir. Diğer seçeneğinde, Kurumsal Sosyal Sorumluluk faaliyetlerinin toplumsal yararlarıyla ilgili olarak yapılan açıklamalar şunlardır: 1.Kurumsal Sosyal Sorumluluk faaliyetleri kurum bilinirliğini artırmak için yapılır, 2.Kurumsal Sosyal Sorumluluk faaliyetleri farkındalığı arttırır, 3.Kurumsal Sosyal Sorumluluk faaliyetleri birlik ve beraberlik sağlar, 4.Kurumsal Sosyal Sorumluluk faaliyetleri faaliyet konusu ile ilgili farkındalık oluşturur, 5.Kurumlar toplum içinde yardıma ihtiyaç duyulan konuları üstlenerek sorunların çözümünde etkin bir rol oynayabilirler. Bu da toplum içinde sorunların daha kolay çözümünü sağlar, paylaşımı arttırır aynı zamanda devletin üzerindeki yükün azalmasında katkıda bulunur. Sorunlar daha kısa sürede çözülebileceğinden zaman tasarrufu sağlar, 6.Kurumsal Sosyal Sorumluluk faaliyetleri kanunlarla, kurumlar için 
zorunlu hale getirilmelidir, 7.Kurumsal Sosyal Sorumluluk faaliyetleri topluma fayda sağlar, 8.Kurumsal Sosyal Sorumluluk toplumun eğitim seviyesi, sosyal sorumluluk bilincini sağlar. Yeni alanlar yaratır, 9.Kurumsal Sosyal Sorumluluk toplumsal değişime yön verir, 10.Kurumsal Sosyal Sorumluluk faaliyetleri toplumsal birliği arttırır, 11.Kurumsal Sosyal Sorumluluk faaliyetleri temiz bir toplumunun oluşumuna katkı sağlar, 12.Kurumsal Sosyal Sorumluluk faaliyetleri çalışanlar arasında toplumsal dayanışmayı arttırır, 13.Kurumsal Sosyal Sorumluluk faaliyetleri insanın insana sahiplenme duygusunu arttırır, 14.Kurumsal Sosyal Sorumluluk faaliyetleri kurumsal bilinirliği ve saygınlığı arttırır, 15.Kurumsal Sosyal Sorumluk faaliyetleri yardımlaşmayı arttırır, 16.Kurumsal Sosyal Sorumluluk faaliyetleri ekonomiye katkı sağlar, 17.Kurumsal Sosyal Sorumluluk faaliyetleri STK'ların yaşamlarını sürdürebilmelerine katkı sağlar, 18.Kurumsal Sosyal Sorumluluk faaliyetleri sürdürebilir büyümeye katkı sağlar.

Tablo 8. Kurumsal Sosyal Sorumluluk Faaliyetlerinin Kurumsal Yararlar Anlayışına Göre Dağılımı

\begin{tabular}{|c|c|c|c|c|c|c|}
\hline $\begin{array}{l}\text { KSS faaliyetlerinin kurumsal } \\
\text { yararlarıla ilgili olarak aşağıda } \\
\text { yer alan ifadelerin sizin için } \\
\text { katılım derecelerini belirtiniz. }\end{array}$ & $\begin{array}{c}\text { Frekans (n) } \\
\text { ve } \\
\text { Yüzde } \\
(\%)\end{array}$ & 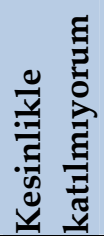 & 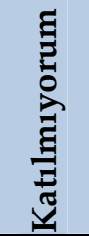 & 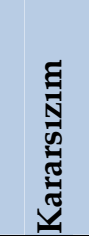 & 离 & 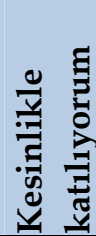 \\
\hline \multirow{2}{*}{ KSS, karlılıkta artış sağlar. } & Frekans (n) & 9 & 41 & 21 & 27 & 6 \\
\hline & Yüzde (\%) & 8,6 & 39,4 & 20,1 & 25,9 & 5,7 \\
\hline \multirow{2}{*}{ KSS, rekabet avantajı sağlar. } & Frekans (n) & 4 & 21 & 22 & 43 & 14 \\
\hline & Yüzde (\%) & 3,8 & 20,1 & 21,1 & 41,3 & 13,4 \\
\hline \multirow{2}{*}{$\begin{array}{l}\text { KSS, kurumsal imaj ve itibarı } \\
\text { artırır. }\end{array}$} & Frekans (n) & 1 & 2 & 5 & 27 & 69 \\
\hline & Yüzde (\%) & 0,9 & 1,9 & 4,8 & 25,9 & 66,3 \\
\hline \multirow{2}{*}{ KSS, müşteri sadakatini artırır. } & Frekans (n) & 1 & 5 & 18 & 51 & 29 \\
\hline & Yüzde (\%) & 0,9 & 4,8 & 17,3 & 49,0 & 27,8 \\
\hline \multirow{2}{*}{$\begin{array}{l}\text { KSS, çalışan memnuniyetini ve } \\
\text { bağlılığını artırır. }\end{array}$} & Frekans (n) & 1 & 4 & 13 & 54 & 32 \\
\hline & Yüzde (\%) & 0,9 & 3,8 & 12,5 & 51,9 & 30,7 \\
\hline \multirow{2}{*}{ KSS, verimlilik ve kaliteyi artırır. } & Frekans (n) & 2 & 19 & 28 & 34 & 21 \\
\hline & Yüzde (\%) & 1,9 & 18,2 & 26,9 & 32,6 & 20,1 \\
\hline \multirow{2}{*}{$\begin{array}{l}\text { KSS, risk yönetiminin etkinliğini } \\
\text { artırır. }\end{array}$} & Frekans (n) & 2 & 28 & 31 & 26 & 17 \\
\hline & Yüzde (\%) & 1,9 & 26,9 & 29,8 & 25 & 16,3 \\
\hline \multirow{2}{*}{$\begin{array}{l}\text { KSS, kurumları aktivist } \\
\text { saldırılara karşı korur. }\end{array}$} & Frekans (n) & 6 & 20 & 28 & 39 & 11 \\
\hline & Yüzde (\%) & 5,7 & 19,2 & 26,9 & 37,5 & 10,5 \\
\hline \multirow{2}{*}{$\begin{array}{l}\text { KSS, kurumsal paydaşlarla } \\
\text { ilişkileri geliştirir. }\end{array}$} & Frekans (n) & 1 & 0 & 15 & 53 & 35 \\
\hline & Yüzde (\%) & 0,9 & 0 & 14,4 & 50,9 & 33,6 \\
\hline \multirow{2}{*}{$\begin{array}{l}\text { KSS, yeni pazarlara girmede } \\
\text { avantaj sağlar. }\end{array}$} & Frekans (n) & 4 & 25 & 32 & 27 & 16 \\
\hline & Yüzde (\%) & 3,8 & 24,0 & 30,7 & 25,9 & 15,3 \\
\hline
\end{tabular}

Kurumsal Sosyal Sorumluluk faaliyetlerinin kurumsal yararlarına ilişkin soruya verilen yanıtların dağılımı Tablo 8'de incelenmiştir. Buna göre "KSS karlılıkta artış sağlar." ifadesini araştırmaya katılanların 9'u (\% 8,6) kesinlikle katılmıyorum, 41'i (\% 39,4) katılmıyorum, 21'i $(\%$ 20,1) kararsızım, 27'si (\% 25,9) katıliyorum ve 6'sı (\%5,7) kesinlikle katıliyorum olarak yanıtlamıştır. "KSS, rekabet avantajı sağlar." ifadesini araştırmaya katılanların 4'ü $(\% 3,8)$ 
kesinlikle katılmıyorum, 21'i (\% 20,1) katılmıyorum, 22'si (\%21,1) kararsızım, 43'ü (\%41,3) katılıyorum ve 14 'ü $(\% 13,4)$ kesinlikle katılıyorum olarak yanıtlamıştır. “KSS, kurumsal imaj ve itibarı artırır." ifadesini araştırmaya katılanların 1'i (0,9\%) kesinlikle katılmıyorum, 2'si (1,9\%) katılmiyorum, 5'i (\% 4,8) kararsızım, 27'si (\% 25,9) katıliyorum ve 69'u (\% 66,3) kesinlikle katılıyorum olarak yanıtlamıştır. "KSS, müşteri sadakatini artırır." ifadesini araştırmaya katılanların 1'i (\% 0,9) kesinlikle katılmıyorum, 5'i (\% 4,8) katılmıyorum, 18'i (\% $17,3)$ kararsızım, 51'i (\% 49,0) katılıyorum ve 29'u (\% 27,8) kesinlikle katıliyorum olarak yanıtlamıştır. "KSS, çalışan memnuniyetini ve bağlılığını artırır." ifadesini araştırmaya katılanların 1'i (\% 0,9) kesinlikle katılmıyorum, 4'ü (\% 3,8) katılmıyorum, 13'ü (\% 12,5) kararsızım, 54'ü (\% 51,9) katılıyorum ve 32'si (\% 30,7) kesinlikle katılıyorum olarak yanıtlamıştır. "KSS, verimlilik ve kaliteyi artırır." ifadesini araştırmaya katılanların 2'si (\% 1,9) kesinlikle katılmiyorum, 19'u (\%18,2) katılmiyorum, 28'i $(\% 26,9)$ kararsizım, 34'ü (\% 32,6) katılıyorum ve 21'i (\% 20,1) kesinlikle katılıyorum olarak yanıtlamıştır. "KSS, risk yönetiminin etkinliğini arttırır." ifadesini araştırmaya katılanların 2'si (\% 1,9) kesinlikle katılmiyorum, 28'i (\% 26,9) katılmıyorum, 31'i (\% 29,8) kararsızım, 26's1 (\% 25) katıliyorum ve 17 'si $(\%$ 16,3) kesinlikle katılıyorum olarak yanıtlamıştır. "KSS, kurumları aktivist saldırılara karşı korur." ifadesini araştırmaya katılanların 6'sı (\% 5,7) kesinlikle katılmiyorum, 20'si (\%19,2) katılmiyorum, 28'i (\% 26,9) kararsızım, 39'u (\% 37,5) katıliyorum ve 11'i (\% 10,5) kesinlikle katılıyorum olarak yantlamıştır. “KSS, kurumsal paydaşlarla ilişkileri geliştirir." ifadesini araştırmaya katılanların 1'i $(\% 0,9)$ kesinlikle katılmıyorum, 0'1 (\% 0) katılmıorum, 15'i (\% 14,4) kararsızım, 53'ü (\%50,9) katıllyorum ve 35'i $(\% 33,6)$ kesinlikle katılıyorum olarak yanıtlamıştır. "KSS, yeni pazarlara girmede avantaj sağlar." ifadesini araştırmaya katılanların 4'ü (\% 3,8) kesinlikle katılmıyorum, 25'i (\% 24,0) katılmıyorum, 32'si (\% 30,7) kararsızım, 27'si (\%25,9) katılıyorum ve 16's1 (\% 15,3) kesinlikle katılıyorum olarak yanıtlamıştır. Araştırmaya katılanların $14^{\prime}$ ü $(\% 13,4)$ anket formunun altıncı sorusunda yer alan diğger seçeneğini de işaretlemiştir. Diğer seçeneğinde Kurumsal Sosyal Sorumluluk faaliyetlerinin kurumsal yararlarıyla ilgili olarak yapılan açıklamalar şunlardır: 1.Kurumsal Sosyal Sorumluluk faaliyetleri toplum tarafından kabul ve sempatiyi arttırır, 2.Kurumsal Sosyal Sorumluluk faaliyetleri kurum kültürünü arttırır, 3.Kurumsal Sosyal Sorumluluk kurumun sadece fiyatlarla değil de değerlerle de ilgilendiğini göstermesi açısından önemlidir, 4.Kurumsal Sosyal Sorumluluk faaliyetleri kurumsal tanıtım açısından önemlidir. Yapılan faaliyetlerle daha geniş kitlelerin kurum hakkında olumlu bilgi sahibi olmasını sağlar. Kuruma toplum tarafından tercih önceliği sağlar, 5.Faaliyet konusu ile ilgili sektörde öncülük eder ve dikkati çeker, 6.Her büyük şirket Kurumsal Sosyal Sorumluluk faaliyetlerinde bulunmalıdır, 7.Kurumsal Sosyal Sorumluluk faaliyetleri biz bilincini geliştirir, 8.Kurumsal Sosyal Sorumluluk faaliyetleri marka bilinirliğine katkı sağlar, 9.Kurumsal Sosyal Sorumluluk faaliyetlerinin satışlarda etkisi olduğunu düşünmüyorum, 10.Kurumsal Sosyal Sorumluluk faaliyetleri yurtdışı işlerimize katkı sağlar, 11.Kurumsal Sosyal Sorumluluk faaliyetleri alınacak yeni personelin çıtasını yüksek tutmasını ve cazibesini artırır, 12. Kurumsal Sosyal Sorumluluk faaliyetleri kurumun topluma olan saygısını gösterir, 13. Kurumsal Sosyal Sorumluluk faaliyetleri nitelikli iş gücünü çekmede katkı sağlar, 14.Hedef müşteri kitlesinin sosyo ekonomik karakteristiğine bağlı olarak rekabet avantajı ve müşteri sadakati sağlar. 
Tablo 9. Kurumların Gerçekleştirdikleri Sosyal Sorumluluk Faaliyetlerinin Kurumsal Web Sitelerinde Yer Alıp Almamasına İlişkin Dağılım

\begin{tabular}{|l|c|c|c|}
\hline $\begin{array}{l}\text { Kurumların KSS faliyetleri kurumsal web } \\
\text { sitelerinde yer alıyor mu? }\end{array}$ & $\begin{array}{c}\text { Yer alıyor/ } \\
\text { Yer almıyor }\end{array}$ & Frekans(n) & Yüzde(\%) \\
\hline $\begin{array}{l}\text { KSS uygulamalarında sadece toplum yararı } \\
\text { gözettiklerini belirten kurumlar }\end{array}$ & Yer alıyor & 14 & $\% 37,8$ \\
\cline { 2 - 4 } & Yer almıyor & 23 & $\% 62,1$ \\
\hline $\begin{array}{l}\text { KSS uygulamalarında hem toplum hem } \\
\text { kurum yararı gözettiklerini belirten } \\
\text { kurumlar }\end{array}$ & Yer alıyor & 53 & $\% 79,1$ \\
\cline { 2 - 4 } & Yer almıyor & 14 & $\% 20,8$ \\
\hline
\end{tabular}

Kurumların KSS faaliyetlerinin kurumsal web sitelerinde yer alıp almamasına ilişkin dağılım Tablo 9'da incelenmektedir. Kurumsal Sosyal Sorumluluk uygulamalarından sadece toplum yararı gözettiklerini belirten 37 şirketten 14'ünün $(\% 37,8)$ gerçekleştirdikleri sosyal sorumluluk projeleri kurumsal web sitelerinde yer alırken $23(\%$ 67,6) şirket bu çalışmalarına web sitelerinde yer vermemiştir. Ayrıca, KSS uygulamalarından hem toplum hem kurum yararı gözettiklerini belirten 67 şirketten 53'ünün $(\% 79,1)$ sosyal sorumluluk projeleri kurumsal web sitelerinde yer alırken 14 'ünün (\% 20,8) bu tür faaliyeteri web sitelerinde yer almamıştır.

\section{SONUÇ}

Sanayileşmenin getirdiği sorunlar ve bu sorunların çevre, kamu sağlığı ve işçilerin refahı üzerindeki etkileri, şirketlerin sosyal sorumluluklarının sorgulanmaya başlanmasına neden olmuştur. Buna bağlı olarak yeni beklentilerin ortaya çıkması, önceleri sadece kar amacı güden kurumların bulundukları sosyal çevrede bir takım sorumluluklar üstlenmesini zorunlu hale getirmiştir. İlk başlarda toplumdan gelen baskılar karşısında ekonomik ve politik anlamda bir zorunluluk olarak yerine getirilen ve sadece hissedarlar, müşteriler gibi kurumla doğrudan ilgili paydaşlarla ilgili konularla sınırlı kalan Kurumsal Sosyal Sorumluluk anlayışının, zamanla bir gönüllülüğe dönüşerek toplumun ihtiyaç ve beklentilerine göre çeşitli alanlara yayıldığı̆, kurumların sadece paydaşlarına karşı değil tüm topluma ve çevreye karşı sorumlu olduklarının bilincine varmış oldukları görülmektedir.

Bu çalışmanın amacı öncelikle, Türkiye'de özel sektör tarafından gerçekleştirilen Kurumsal Sosyal Sorumluluk faaliyetlerine ilişkin toplumsal ve kurumsal yarar algılarının ortaya konulmasıdır. Çalışmada veri toplama aracı olarak anket çalışması ve kurumsal web sitelerine yönelik içerik analizi uygulanmıştır. Anket sorularını şirketlerin Kurumsal Sosyal Sorumluluk faaliyetlerini yürüten ilgili kişiler yanıtlamıştır. Bu kişilerin cinsiyet dağılımlarına göre, kadınların oranı $(\%$ 64,4) erkeklerin oranının $(\% 35,5)$ neredeyse iki katını oluşturmaktadır. Araştırma sorularını yanıtlayanların \% 90,3'ü lisans ve üstü eğitim düzeyine sahipken, \% 31,7'si en yüksek oranla 31-35 yaş aralığında yer almaktadır. 
Araştırmanın sonucuna göre, Kurumsal Sosyal Sorumluluk faaliyetlerinin en fazla Kurumsal İletişim $(\%$ 39,4) ve İnsan Kaynakları Departmanı (\% 36,5) tarafından yürütüldüğü görülmektedir. Araştırmaya katılan bazı şirketler holding kuruluşlarıdır. Holding bünyesinde tek bir Kurumsal İletişim Departmanı mevcuttur ve Kurumsal Sosyal Sorumluluk çalışmaları holding şirketlerinin bünyesindeki İnsan Kaynakları departmanıyla koordineli olarak yürütülmektedir. Araştırmanın sonucunda İnsan Kaynakları departmanının bu kadar yüksek çıkmasının sebebi budur. Dolayısıyla Türkiye'deki şirketlerin Kurumsal Sosyal Sorumluluk faaliyetlerinin büyük bir oranla Kurumsal İletişim Departmanları tarafından gerçekleştirildiği söylenebilir.

Kurumsal Sorumluluk faaliyetlerinin yoğunlaştığı alanlara bakıldığında eğitim ve öğretim konusunun \%78,8 oranıyla diğer alanlara göre oldukça öne çıtı̆̆ı görülmektedir. Eğitim konusunu \% 47,1'le doğa ve çevre konusu takip etmektedir. En az spor alanında (\% $18,3)$ faaliyette bulunulduğu görülmektedir.

Araştırmanın sonucuna göre, Kurumsal Sosyal Sorumluluk uygulamalarında sadece kurum yararı gözeten şirket bulunmamaktadır. Araştırmaya katılanların \% 35,6'sının Kurumsal Sosyal Sorumluluk uygulamalarında toplum yararı gözettiği, \% 64,4'nin Kurumsal Sosyal Sorumluluk uygulamalarında hem toplum hem kurum yararı gözettiği görülmektedir. Kurumsal Sosyal Sorumluluk faaliyetlerinin sağladığı toplumsal yararlarla ilgili ifadelere katılanların oranı ortalama \% 85,6 iken Kurumsal Sosyal Sorumluluk faaliyetlerinin sağladığı kurumsal yararlarlarla ilgili ifadelere katılanların oranı ise ortalama $\%$ 60,6'dir.

Dolayısıyla şirketlerin büyük bir çoğunluğu Kurumsal Sosyal Sorumluluk faaliyetlerinin kurumsal yararları olduğunu kabul etse de toplumsal yararlarının kurumsal yararlarından fazla olduğu görüşündedir. Şirketler, Kurumsal Sosyal Sorumluluk faaliyetlerinin en büyük toplumsal yaralarlarının çevreye karşı toplumdaki bilinçliliği arttırması (\% 94,2), toplumsal refahı iyileştirmesi $(\%$ 90,3) ve eğitimin yaygınlaşmasını sağlaması (\% 89,4)olarak belirtmektedir. Kurumsal Sosyal Sorumluluk faaliyetlerinin toplumsal yararlarına ilişkin, "KSS tüketicilerin yaşam kalitesini yükseltir." ifadesine ise şirketler, \% 63,3 oranla en düşük katılımı göstermişlerdir. Kurumsal Sosyal Sorumluluk faaliyetlerinin en büyük kurumsal yararlarıyla ilgili olarak şirketlerin görüşleri ise, kurumsal imaj ve itibarı arttıracağı $(\% 92,2)$, kurumsal paydaşlarla ilişkileri geliştireceği $(\%$ 84,5) ve çalışan memnuniyet ve bağl1lı̆̆ını artıracağı $(\%$ 82,6) yönündedir. Kurumsal Sosyal Sorumluluk faaliyetlerinin kurumsal yararlarına ilişkin, "KSS karlılıkta artış sağlar." ifadesine ise şirketler, \% 31,6 oranla en düşük katılımı göstermişlerdir.

Kısaca araştırmanın sonucuna göre, şirketlerin büyük bir çoğunluğu KSS faaliyetlerinin toplumsal yararlarının kurumsal yararlarından fazla olduğu görüşünde olsa da Kurumsal Sosyal Sorumluluk faaliyetlerinde, temelde iki taraflı yarar gözetilmektedir. Bu nedenle kurum yararının gerçekleşebilmesi için kurumsal sosyal sorumluluk çalışmalarından kamuoyunun haberdar edilebilmesi önem taşımaktadır. Günümüzde kurumsal web sitelerinin bu çalışmaların duyurulmasında etkin bir şekilde kullanıldığı görülmektedir. Bu doğrultuda araştırmaya katılan şirketlerin kurumsal web siteleri analiz edilmiş ve KSS faaliyetlerinin kurumsal web sitelerinde duyurulup duyurulmadığ belirlenmiştir. 
Araştırmanın sonucuna göre Kurumsal Sosyal Sorumluluk uygulamalarından sadece toplum yararı gözettiklerini belirten 37 şirketten 14'ünün $(\%$ 37,8) gerçekleştirdikleri sosyal sorumluluk projeleri kurumsal web sitelerinde yer alırken $23(\%$ 67,6) şirket bu çalışmalarına web sitelerinde yer vermemiştir. Ayrıca, KSS uygulamalarından hem toplum hem kurum yararı gözettiklerini belirten 67 şirketten 53'ünün $(\% 79,1)$ sosyal sorumluluk projeleri kurumsal web sitelerinde yer alırken 14 'ünün $(\%$ 20,8) bu tür faaliyeteri web sitelerinde yer almamıştır.

Sonuç olarak en genel tanımıyla Kurumsal Sosyal Sorumluluk, bir kurumun tüm paydaşlarına karşı sorumlu davranmasını ifade etmektedir. Karşılıklı faydaya dayalı ilişkilerden oluşan toplumsal düzen içinde sorumluluk, hem bireysel hem kurumsal anlamda toplum halinde yaşamanın bir gereği olarak görülmektedir. Toplumu oluşturan birçok farklı kamuyla ilişki içerisinde olan kurumların kendi varlıklarını sürdürebilmeleri, toplumu oluşturan ötekilerin de çıkarlarını gözetmesi, haklarına saygı duyması ve toplumdaki sorunların çözümüne katkı sağlamasıyla mümkün olmaktadır. Bu doğrultuda, Türkiye'de özel sektör tarafından gerçekleştirilen Kurumsal Sosyal Sorumluluk faaliyetlerinde hem kurum hem toplum yararı gözetildiği fakat toplum yararının kurumsal yarardan daha ön planda tutulduğu görülmektedir. Ayrıca kurum yararının gerçekleşebilmesi için bu tür faaliyetlerin duyurulmasında şirketlerin, kurumsal web sitelerinden etkin olarak yararlandıkları da belirlenmiştir.

\section{KAYNAKÇA}

Aktan, Coşkun Can ve Deniz Börü (2007). Kurumsal Sosyal Sorumluluk. Kurumsal Sosyal Sorumluluk: İşletmeler ve Sosyal Sorumluluk. Ed.Coşkun Can Aktan. İstanbul: İGİAD Yayınları:4, s.14.

Böke, Kaan (2009). Örnekleme. Sosyal Bilimlerde Araştırma Yöntemler., Ed. Kaan Böke. 2.bs.. İstanbul: Alfa Yayinları, s.106.

Ersöz, Halis Yunus (2007). Türkiye'de Kurumsal Sosyal Sorumluluk Anlayışının Gelişiminde Meslek ve Sivil Toplum Kuruluşları. İstanbul: İstanbul Ticaret Odası Yayınları. Yayın No:2007-36.

Goodpaster, Kenneth E. ve John B. Mathews (2003). Can a Corporation Have a Consciences?. Harvard Business Review on Corporate Responsibility. United States: Harvard Business School Publishing Corporation, p.141.

Göcenoğlu, Ceyhun, Işın Onan (2008). Türkiye' de Kurumsal Sosyal Sorumluluk Değerlendirme Raporu. Avrupa Komisyonu. S.7. (Çevirimiçi) http://www.unglobalcompact.org/docs/networks_around_world_doc/Network_material/CS R_Report_in_Turkish.pdf, 4 Eylü 2008.

Grunig, James E. Ve Jon White (2005). “Halkla İlişkiler Kuram ve Uygulamasında Dünya Görüşlerinin Etkisi. Halkla İlişkiler ve İletişim Yönetiminde Mükemmellik, Ed.Serra Görpe, Çev. Elif Özsayar, İstanbul: Rota Yayınları.

Gürel, Tuğçe (2010). Kurumsal Sosyal Sorumlulukta Yeni Yaklaşımlar ve Tartışılan Konular. Selçuk Üniversitesi İletişim Fakültesi Akademik Dergisi. Cilt:6, Sayı:3, Temmuz, s.118. 
Karakadılar, Ömür (2008). Toplam Kalite Yönetimi ve Toplumsal Sorumluluk. (Çevirimiçi) http://omurkarakadilar.8m.com/seminer1.htm, 2 Ekim 2008.

Kotler, Philip ve Nancy Lee (2008). Kurumsal Sosyal Sorumluluk. Çev.Sibel Kaçamak, 2.bs, İstanbul: MediaCat Kitapları.

Kurtkan, Amiran (1978). Sosyal Bilimler Metodolojisi. İstanbul: İstanbul Üniversitesi İktisat Fakültesi Yayınları.

Moir, Lance (2001). What Do We Mean By Corporate Social Responsibility?. Corporate Governance. Vol.1, No: 2, p.19.

Öcal, Aslan Tolga Öcal (2007). İşletmelerin Sosyal Sorumluluğu: Ahlaki Bir Değerlendirme. İstanbul: Beta Basım Yayınları.

Özüpek, Nejat M. (2005). Kurum Imajı ve Sosyal Sorumluluk. Konya: Tablet Kitabevi.

Sevinç, Bilal (2009). Survey Araştırma Yöntemi. Sosyal Bilimlerde Araştırma Yöntemleri. Ed. Kaan Böke, 2.bs., İstanbul: Alfa Yay

Sönmez, Feriştah Bircan, Kamil (2004). İşletmelerin Sosyal Sorumluluğu ve Çevre Sorunlarında Ekonomik Yaklaşımlar. Yaklaşım Dergisi. Yıl:12, Sayı:133, Ocak, ss.476-490.

Stoner,James A.F. ve R. Edward Freeman, Daniel R. Gilbert Jr. (1995). Management. 6th Edition, Prentice- Hall International, Inc.

Theaker, Alison (2006). Halkla İlişkilerin El Kitabı. Çev. Murat Yaz, İstanbul: MediaCat Yayınları.

Türkçe Sözlük (1988). Ankara: Türk Dil Kurumu Yayınları.

Van Het Hof, Seçil Deren ve Didem Çabuk (2011). Kurumsal Sosyal Sorumluluk. Dünden Bugüne Halkla İlişsiler. Ed.Metin Işık, Mustafa Akdă̆, 2.bs. Konya: Eğitim Kitapevi. s.49.

Werther, William B. ve David Chandler (2006). Strategic Corporate Social Responsibility: Stakeholders in a Global Environment. London: Sage Publication.

Yamak, Sibel (2007). Kurumsal Sosyal Sorumluluk Kavramının Gelişimi. İstanbul: Beta Yayınları.

Yazar, Faruk (2009). KOBİler ve Kurumsal Sosyal Sorumluluk. Çerçeve Dergisi. Musiad Yayınları: Yıl:16, Sayı:49, Ocak, s.145.

(Çevirimiçi) http://www.sucsr.com/kurumsal-sosyal-sorumluluk/makaleler/kssnedir.php, 11 Mart 2009. 